\title{
Induction of systemic resistance in tomato by the autochthonous phylloplane resident Bacillus cereus
}

\author{
Bernardo de Almeida Halfeld-Vieira(1), José Roberto Vieira Júnior( ${ }^{(2)}$, Reginaldo da Silva Romeiro(2), \\ Harllen Sandro Alves Silva ${ }^{(3)}$ and Maria Cristina Baracat-Pereira ${ }^{(4)}$
}

\begin{abstract}
(1)Embrapa Roraima, BR 174, Km 08, Caixa Postal 133, CEP 69301-970 Boa Vista, RR, Brazil. E-mail: halfeld@cpafrr.embrapa.br (2)Universidade Federal de Viçosa (UFV), Dep. de Fitopatologia, Av. PH Rolfs, s/no CEP 36571-000 Viçosa, MG, Brazil. E-mail: pinhonet@hotmail.com, rromeiro@ufv.br (3)Instituto Biológico, Rod. Heitor Penteado, Km 3, CEP 13001-970 Campinas, SP, Brazil. E-mail: harllen@biologico.sp.gov.br ${ }^{(4)}$ UFV, Dep. de Bioquímica e Biologia Molecular. E-mail: baracat@ufv.br
\end{abstract}

\begin{abstract}
The objective of this work was to verify if the induced resistance mechanism is responsible for the capacity of a phylloplane resident bacteria (Bacillus cereus), isolated from healthy tomato plants, to control several diseases of this crop. A strain of Pseudomonas syringae pv. tomato was used as the challenging pathogen. The absence of direct antibiosis of the antagonist against the pathogen, the significant increase in peroxidases activity in tomato plants exposed to the antagonist and then inoculated with the challenging pathogen, as well as the character of the protection, are evidences wich suggest that biocontrol efficiency presented by the antagonist in previous works might be due to induced systemic resistance (ISR).
\end{abstract}

Index terms: Lycopersicon esculentum, Solanum esculentum, biological control.

\section{Indução de resistência sistêmica em tomateiro pela bactéria autóctone residente no filoplano Bacillus cereus}

\begin{abstract}
Resumo - O objetivo deste trabalho foi investigar se o mecanismo de indução de resistência é responsável pela capacidade de um isolado bacteriano residente no filoplano (Bacillus cereus), obtido de plantas sadias de tomateiro, em controlar diversas doenças da cultura. A fim de investigar o modo de ação envolvido no controle, foi utilizado um isolado de Pseudomonas syringae pv. tomato como patógeno desafiador. A ausência do mecanismo de antibiose contra o patógeno, o aumento significativo dos níveis de peroxidases em plantas expostas ao antagonista e submetidas à inoculação do patógeno desafiador, assim como a sistemicidade da proteção, são evidências que sugerem que o mecanismo de biocontrole em questão se refere à indução de resistência sistêmica (IRS).
\end{abstract}

Termos para indexação: Lycopersicon esculentum, Solanum esculentum, controle biológico.

\section{Introduction}

Systemic resistance to diseases in plants can be induced by abiotic or biotic elicitors (Heil, 2001). Among biotic inducers of systemic resistance, plant growthpromoting rhizobacteria (PGPR) seems to be the best studied organisms, as they have been reported as the responsible for the systemic resistance (ISR) against plant pathogenic fungi (Jetiyanon et al., 2003), bacteria (Silva et al., 2004), nematodes (Kokalis et al., 2002), and viruses (Murphy et al., 2003).

Not much work was performed on the ability of prokaryotic phylloplane residents as promoters of biocontrol of plant diseases through ISR mechanisms. Bargabus et al. (2004) demonstrated that an isolate of
Bacillus mycoides obtained from the sugarbeet phylloplane was able to control cercospora leaf spot (Cercospora beticola).

There are some criteria to be used as guidelines to clarify whether the observed protection brought about by a biocontrol agent results from a type of induced resistance. Steiner \& Schönbeck (1995) stated that an elicitor of induced resistance is not expected to cause direct toxic effects on the pathogen. Another is that activities of some specific enzymes increases in plant tissues exposed to the alleged elicitor just after the inoculation with a challenging pathogen (Sticher et al., 1997). Lipoxygenases (Porta \& Rocha-Sosa, 2002), $\beta$-1,3-glucanases (Van Loon et al., 1994), phenylalanine amonia-lyases (Sharan et al., 1998), and polyphenoloxidases (Li \& Steffens, 2002) are among these indicator enzymes of this so-called "induced state". 
Peroxidases (PO) are related to the hypersensitive responses (HR) (Martinez et al., 1998), lignin and suberin syntheses (Quiroga et al., 2000), and oxidation of phenolic compounds (van Huystee, 1987). Another important aspect in ISR is that biotic non-pathogenic biocontrol agents in plants often induce resistance with characteristics of systemicity (Sticher et al., 1997).

Halfeld-Vieira (2002) isolated 300 prokaryotic phylloplane residents from healthy tomato plants and tested each isolate as a candidate to control diseases of the aboveground tomato organs. The strain UFV-IEA6, Bacillus cereus, was considered the most promising among them. Results from greenhouse and field experiments suggested that this isolate acted indirectly rather than directly against several tomato pathogens. Besides, UFV-IEA6 protected tomato plants against multiple phylloplane diseases, a well-known feature of induced resistance (Halfeld-Vieira et al., 2004).

This work was carried out to verify if the ISR mechanism is responsible for the capacity of a phylloplane resident bacteria (Bacillus cereus) to control several diseases of tomato.

\section{Material and Methods}

Experiments were carried out at the Laboratory of Plant Bacteriology and Biological Control, Department of Plant Pathology, Universidade Federal de Viçosa, Brazil. Santa Cruz 'Kada' tomato plants were established in sterilized soil in a greenhouse, under conditions of partially-controlled temperature and relative humidity.

The phylloplane resident bacteria UFV-IEA6 and the pathogen Pseudomonas syringae pv. tomato (Pst) were grown in medium 523 (Kado \& Heskett, 1970). Cultures of tomato pathogens were obtained from the collection of the Department of Plant Pathology, Universidade Federal de Viçosa. UFV-IEA6, identified as Bacillus cereus by fatty-acid analysis, was isolated from the phylloplane of healthy tomato, tested and selected as a control agent of tomato leaf diseases (Halfeld-Vieira, 2002; Halfeld-Vieira et al., 2004).

To fulfill one of the criteria suggested by Steiner \& Schönbeck (1995), a claimed direct antibiosis against the challenging pathogen was the hypothesis tested by the overlay diffusion method, according to a procedure by Romeiro (2001). From a liquid culture in the exponential growth phase a loop-full of the antagonist was transferred to 523 medium (Kado \& Heskett, 1970) inside Petri dishes and kept for 24 hours at $25^{\circ} \mathrm{C}$. The antagonist was killed by one-hour exposure to chloroform vapors and, once the volatilization was over, one mm-thick overlay was produced when melted semisolid culture media $\left(0.8 \% \mathrm{w} \mathrm{v}^{-1}\right.$ agar, $\left.48^{\circ} \mathrm{C}\right)$, containing Pst cells at $10 \mu \mathrm{L}$ per mL of melted culture medium was poured into each Petri dish. Bioassay plates were moved to an incubator at $25^{\circ} \mathrm{C}$ and checked every day, for a whole week, for presence of inhibition haloes.

To colonize phylloplane, a UFV-IEA6 cell suspension in water, harvested in the exponential phase and adjusted for 0.3 of absorbance at $540 \mathrm{~nm}\left(\mathrm{OD}_{540}\right)$ was sprayed on leaves and stems of 16 Santa Cruz 'Kada' tomato plants at the five fully-expanded leaf stage. As control, an equal number of 16 tomato plants was sprayed with water. Four days later, eight plants in the 16 UFV-IEA6sprayed tomato plants were left with the antagonist only (no challenger), and the other eight inoculated with Pst, the challenging pathogen, with a cell suspension at $\mathrm{OD}_{540}=0.1$, following the procedure described by Romeiro (2001). When the typical bacterial speck symptoms appeared, about ten days later, 30 leaflets were harvested from each four groups of eight plants, wrapped up in aluminum foil and stored at $-80^{\circ} \mathrm{C}$. Ten leaflets of each group consisted of one replicate. The four treatments consisted of plants sprayed with water only; plants exposed to the antagonist alone; plants sprayed with water and later inoculated with Pst; plants exposed to the antagonist and post-inoculated with Pst.

Leaf extracts were prepared by grinding frozen leaves in liquid nitrogen, with pestle in a mortar, and thorough mixing of the resulting powder with $50 \mathrm{mM}, \mathrm{pH} 6.5$ sodium phosphate buffer, amended with $1 \% \mathrm{w} \mathrm{v}^{-1}$ polyvinilpirrolidone and $1 \mathrm{nM}$ phenylmethyl-sulfonamide (PMSM), in the rate of $3 \mathrm{~mL}$ of extracting solution per gram of frozen leaves. Extracts were centrifuged at $20,000 \mathrm{~g}$, for $25 \mathrm{~min}$, at $4^{\circ} \mathrm{C}$, the supernatant collected and kept in an ice bath until use (Baracat-Pereira et al., 2001). Peroxidases activities in leaf extracts were quantified according to Hammerschmidt et al. (1982), readings taken at $470 \mathrm{~nm}$, in an U-3000 Hitachi spectrophotometer, precisely 0.5 and 15.5 minutes after mixing reagents and extract. Results were expressed as absorbance units of PO mg-1 tissue min $^{-1}$. Statistical analysis was accomplished in the 8.00 SAS version, and the Tukey test was adopted to compare means.

UFV-IEA6 cells were collected in the exponential growth phase and the inoculum suspension set at $0.5 \mathrm{OD}_{540}$ was sprayed on a pair of top or bottom 45-day-old Santa Cruz 'Kada' tomato plants leaves. To 
accomplish it, each fully-expanded pair of leaves were involved separately in plastic bags, and into each of these a manual sprayer was introduced in such way that the antagonist cells could not fall on any of the remaining aerial plant parts. Once spraying was over, the device was carefully retrieved and the bag sealed. Initially treatments consisted of exposing the bottom leaf pair of each tomato plant to the antagonist and then applying the challenger only on the third leaf pair above (Figure 1); secondly, the other way around, the plastic bags on the top-young leaf pair, and the challenger inoculated later only on the third leaf below. The plastic bags were maintained in place for four days to prevent spread to the adjacent leaves. Then the antagonistsprayed pair of leaves with plastic bags were cut at the base, near the stem, and discarded.

The unexposed, remaining plant parts were then inoculated with the challenging pathogen, Pst, with inoculum set at $0.2 \mathrm{OD}_{540}$. Plants were kept for ten days in a growth chamber, at $26^{\circ} \mathrm{C}$, until typical symptoms became evident. The disease was quantified based on the lesions counts and results expressed as average number of lesions per leaflet. Ten replicates were adopted per treatment, and every treatment consisted of one plant. Statistical analysis was accomplished in the 8.00 SAS version, and the Tukey test was adopted to compare means.

\section{Results and Discussion}

No inhibition haloes were observed when the antagonist UFV-IEA6 (Bacillus cereus) was paired

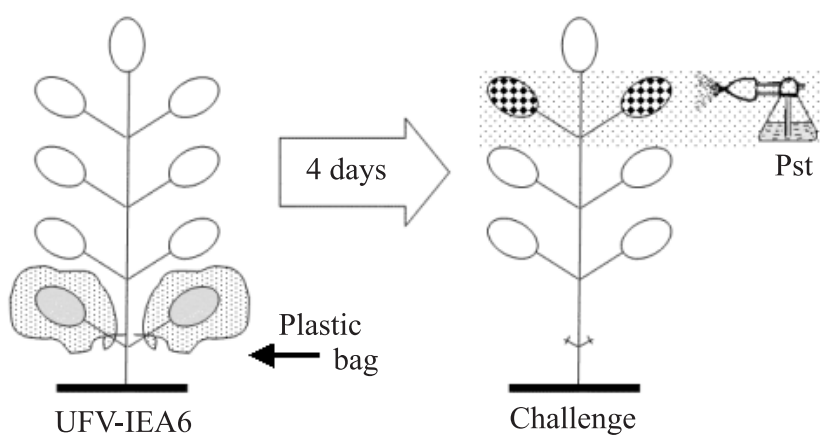

Figure 1. Scheme of the procedure to investigate systemicity of the protection in which a pair of leaves was exposed to the antagonist UFV-IEA6 and a third pair, either above or bellow it, was inoculated with the challenging pathogen Pseudomonas syringae pv. tomato (Pst), four days after exposure. against the challenging pathogen Pst. This means that, within the overlay antibiosis bioassay limits, no direct antibiosis was exerted by UFV-IEA6 Bacillus cereus on Pst.

Plants inoculated with the challenging pathogen, previous exposed to the antagonist living cells, showed significantly higher levels of peroxidases (PO) in their tissues than those from other treatments (Figure 2) and this finding meets the information already available (Sticher et al., 1997), which indicates that tomato plants exposed to the antagonist are in the induced state. The protection against the challenging pathogen due to previous exposure of tomato plants to live cells of the antagonist had characteristics of systemicity (Figure 3). In this sense, unexposed but inoculated leaves in the top showed significantly less lesions after exposure of leaves in the bottom of the same plant. The same occurred after exposure of top leaf pairs and inoculation of unexposed bottom leaves.

Most works on biological control linked to induction of resistance have been accomplished with rhizobacteria (Van Loon et al., 1998a, 1998b) and only a few papers deal with phylloplane residents. Halfeld-Vieira (2002) and Halfeld-Vieira et al. (2004) selected the isolate UFV-IEA6 of Bacillus cereus as a promising antagonist against tomato phylloplane pathogens. The author suggested the observed antagonism has a character of multiplicity, that is, the antagonist, under greenhouse and field conditions, changed a susceptible tomato into a resistant plant, and not only to an specific but to several distinct pathogens (Halfeld-Vieira, 2003; Halfeld-Vieira et al., 2004). The results indicated that, instead of a

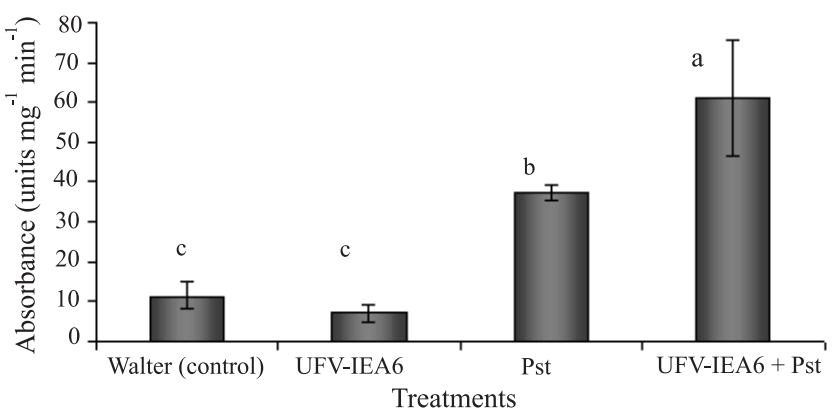

Figure 2. Peroxidases activity in tomato leaves exposed to water (control), the UFV-IEA6 antagonist living cells only, Pseudomonas syringae pv. tomato (Pst) living cells only, or the antagonist living cells, followed by the challenger Pst four days later (UFV-IEA6 + Pst). Averages followed by the same letter do not differ statistically based on Tukey test $(\alpha=0.05)$. 
biocontrol effected by direct antibiosis, one or more mechanisms of induced resistance had become operative.

Tomato plants were changed by UFV-IEA6 from susceptible into resistant ones. No direct antibiosis by the antagonist towards the challenger explains it and there were substantial increases in PO levels in tomato leaves challenged in post-inoculation by an active leaf pathogen. Such resistance was operative in leaves challenged by Pst away from the only leaf pair that received the antagonist, showing that induced resistance explains this data.

Results showed no direct toxic effects by UFV-IEA6 on the challenging pathogen, and this fulfills one of the rules established by Steiner \& Schönbeck (1995) to distinguish induced resistance from other plant defense mechanisms. To Van Loon et al. (1998b) these are useful criteria when the sistemic acquired resistance (SAR) complexities are considered, in the rhizobacteriamediated ISR, for it is difficult to establish whether or not ISR is also involved in an antagonistic response, once it was demonstrated that the antagonist also releases a metabolite that directly inhibits pathogen. They emphasized that even when an antagonist is not present at the site of exposure, an antimicrobial substance could be synthesized by the biocontrol agent and transported through the plant, inhibiting the pathogen directly (Van Loon et al., 1998b).

In this work, plants which received the challenging pathogen after exposure to the antagonist living cells showed significantly higher peroxidases (PO) levels in their tissues than those from other treatments (Figure 2). This finding is validated by previous reports (Sticher et al., 1997), which demonstrated increases in this and other enzymes activities in association with the induced state. In fact, it is known that increased PO levels is an earlier event, detectable once the plant-pathogen interaction has begun (Cook et al., 1995; Harrison et al., 1995; Chittoor et al., 1997). This phenomenon, called oxidative burst (Martinez et al., 1998), leads to a quick synthesis of reactive oxygen derivatives that are involved in activities against pathogens (Wu et al., 1995) and in cell death (Adam et al., 1989). For instance, when a phylloplane resident controlled Cercospora beticola in sugar beets, Bargabus et al. (2004) found that the oxidative burst is the main mechanism therein involved.

A third evidence that the antagonist UFV-IEA6 induces resistance in tomato is the systemicity of the protection observed (Figure 3). According to Steiner \& Schönbeck (1995), the observed resistance in the induced state must be expressed locally and systemically.
As emphasized by several researchers (Sticher et al., 1997; Van Loon et al., 1998b), the induced resistance does not necessarily need to be systemic, but local protection, as a result of induced resistance, is difficult to verify experimentally.

A systemic response of the plant to an elicitor indicates that induced resistance is taking place. As Van Loon et al. (1998b) states, in SAR cases, a mobile signal is generated in the site of induction and translocated in the plant, bringing about an induced state in tissues, far from the site of exposure to the elicitor, while in situations of ISR induced by PGPR, the rhizobacterium is supposed to produce a translocable signal that induces protection in tissues far from the roots where the antagonist was delivered.

There are good evidences that the antagonist protected tomato plants by inducing resistance. This resistance presented systemicity according to the way the experiment was thought out, when a spatial separation between the microbial components of the interaction was carefully accomplished.

To distinguish SAR from ISR, Sticher et al. (1997) suggested some basic guidelines to look at, such as PRPs accumulation, found in SAR and absent in the ISR; signaling pathways, which are clearly distinct in both; visual alteration in plants, e.g. leaf lesions, which are seen in SAR, but not in the ISR; type of elicitor; and range of protection against multiple pathogens. One of

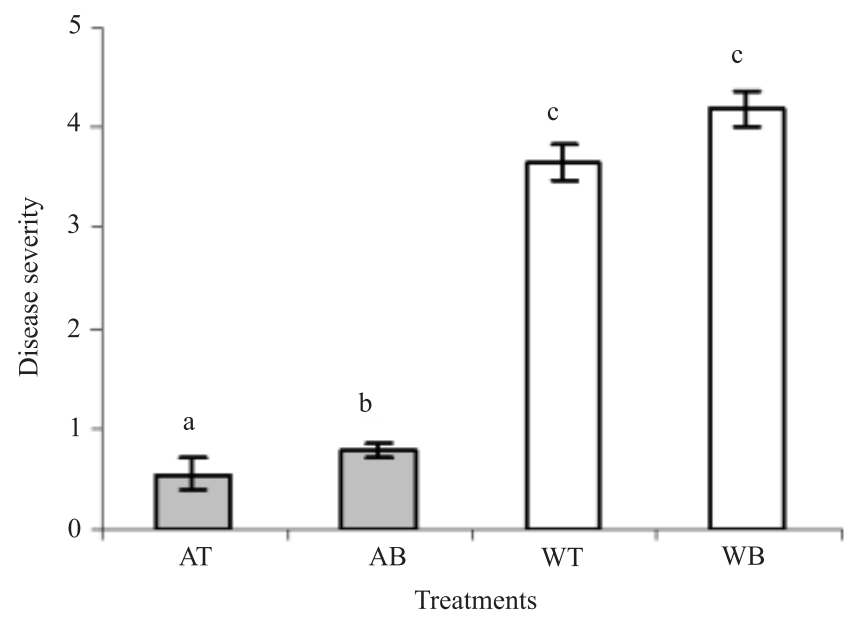

Figure 3. Disease severity expressed as average number of lesions per leaflet in tomato plants after inoculating Pseudomonas syringae pv. tomato in leaf pairs three leaf pairs above (AT, being WT the water control) and bellow ( $A B$, being $\mathrm{WB}$ the water control) leaves exposed to the antagonist UFV-IEA6 (Bacillus cereus). Averages followed by the same letter do not differ statistically based on Tukey test $(\alpha=0.05)$. 
these ISR features, unspecific resistance, had already been met when, based on it and other criteria, HalfeldVieira (2002) and Halfeld-Vieira et al. (2004) selected UFV-IEA6 as promising biocontrol agent based on this and other criteria.

Moreover, concerning the UFV-IEA6-induced resistance, it is also known that UFV-IEA6 causes no lesions on 'Kada' tomato plants and, although surely a biological, it is not a phytopathogenic entity. Currently, no data are available for UFV-IEA6 on the kind of signal pathway generated and if indeed PRP's are not involved. Despite some controversy on terminology good evidences have been presented that UFV-IEA6 is an ISR-inducing antagonist.

\section{Conclusions}

1. The antagonist strain UFV-IEA6 have no direct antibiosis effect against Pseudomonas syringae pv. tomato.

2. Leaf tissues, exposed to Bacillus cereus and inoculated by $P$. syringae pv. tomato, present higher peroxidases (PO) activities.

3. The protection provided by the exposure of leaf tissues to the antagonist presents traits of systemicity.

\section{References}

ADAM, A.; FARKAS, T.; SOMLYAI, G.; HEVESI, M.; KIRÁLY, Z. Consequence of $\mathrm{O}_{2}^{-}$generation during a bacterially induced hypersensitive reaction in tobacco: deterioration of membrane lipids. Physiological and Molecular Plant Pathology, v.34, p.13-26, 1989.

BARACAT-PEREIRA, M.C.; OLIVEIRA, M.G. de A.; BARROS, E.G. de; MOREIRA, M.A.; SANTORO, M.M. Biochemical properties of soybean leaf lypoxigenases: presence of soluble and membrane-bound forms. Plant Physiology and Biochemistry, v.39, p.91-98, 2001.

BARGABUS, R.L.; ZIDACK, N.K.; SHERWOOD, J.E.; JACOBSEN, B.J. Screening for the identification of potential biological control agents that induce systemic acquired resistance in sugar beet. Biological Control, v.30, p.342-350, 2004.

CHITTOOR, J.M.; LEACH, J.E.; WHITE, F.F. Differential induction of a peroxidase gene family during infection of rice by Xanthomonas oryzae pv. oryzae. Molecular Plant-Microbe Interactions, v.10, p.861-871, 1997.

COOK, D.; DREYER, D.; BONNET, D.; HOWELL, M.; NONY, E.; VAN DEN BOSCH, K. Transient induction of a peroxidase gene in Medicago truncatula precedes infection by Rhizobium meliloti. Plant Cell, v.7, p.43-55, 1995.
HALFELD-VIEIRA, B. de A. Bactérias residentes do filoplano de tomateiro como agentes de controle biológico de enfermidades da parte aérea da cultura. 2002. 98p. Tese (Doutorado) Universidade Federal de Viçosa, Viçosa.

HALFELD-VIEIRA, B. de A. Procariotas residentes do filoplano como indutores de resistência - doenças em tomateiro. Summa Phytopathologica, v.29, p.120, 2003.

HALFELD-VIEIRA, B. de A.; ROMEIRO, R.S.; MIZUBUTI, E.S.G. Métodos de isolamento de bactérias do filoplano de tomateiro visando populações específicas e implicações como agentes de biocontrole. Fitopatologia Brasileira, v.29, p.638-643, 2004.

HAMMERSCHMIDT, R.; NUCKLES, E.; KUC, J. Association of enhanced peroxidase activity with induced systemic resistance of cucumber to Colletotrichum lagenarium. Physiological Plant Pathology, v.20, p.73-80, 1982.

HARRISON, S.J.; CURTIS, M.D.; McINTYRE, C.L.; MacLEAN, D.J.; MANNERS, J.M. Differential expression of peroxidase isogenes during the early stages of infection of the tropical forage legume Stylosanthes humilis by Colletotrichum gloeosporioides. Molecular Plant-Microbe Interactions, v.8, p.398-406, 1995.

HEIL, M. The ecological concept of costs of induced systemic resistance (ISR). European Journal of Plant Pathology, v.107, p.137-146, 2001.

JETIYANON, K.; FOWLER, W.D.; KLOEPPER, J.W. Broadspectrum protection against several pathogens by PGPR mixtures under field conditions in Thailand. Plant Disease, v.87, p.13901394, 2003.

KADO, C.I.; HESKETT, M.G. Selective media for isolation of Agrobacterium, Corynebacterium, Erwinia, Pseudomonas and Xanthomonas. Phytopathology, v.60, p.969-976, 1970.

KOKALIS, A.; BURELLE, N.; VAVRINA, C.S.; ROSSKOPF, E.M.; SHELBY, R.A. Field evaluation of plant growth-promoting rhizobacteria amended transplant mixes and soil solarization for tomato and pepper production in Florida. Plant and Soil, v.238, p.257-266, 2002.

LI, L.; STEFFENS, J.C. Overexpression of polyphenol oxidase in transgenic tomato plants results in enhanced bacterial disease resistance. Planta, v.215, p.239-247, 2002.

MARTINEZ, C.; MONTILLET, J.L.; BRESSON, E.; AGNEL, J.P.; DAI, G.H.; DANIEL, J.F.; GEIGER, J.P.; NICOLE, M. Apoplastic peroxidase generates superoxide anions in cells of cotton cotyledons undergoing the hypersensitive reaction to Xanthomonas campestris pv. malvacearum race 18. Molecular Plant-Microbe Interactions, v.11, p.1038-1047, 1998.

MURPHY, J.F.; REDDY, M.S.; RYU, C.M.; KLOEPPER, J.W.; LI, R.H. Rhizobacteria-mediated growth promotion of tomato leads to protection against Cucumber mosaic virus. Phytopathology, v.93, p.1301-1307, 2003.

PORTA, H.; ROCHA-SOSA, M. Plant lypoxigenases. Physiological and molecular features. Plant Physiology, v.130, p.15-21, 2002.

QUIROGA, M.; GUERRERO, C.; BOTELLA, M.A.; BARCELÓ, A.; AMAYA, I.; MEDINA, M.I.; ALONSO, F.J.; FORCHETTI, S.M. de; TIGIER, H.; VALPUESTA, V. A tomato peroxidase involved in the synthesis of lignin and suberin. Plant Physiology, v.122, p.1119-1127, 2000. 
ROMEIRO, R. da S. Métodos em bacteriologia de plantas. Viçosa: UFV, 2001. 279p.

SHARAN, M.; TAGUCHI, G.; GONDA, K.; JOUKE, T.; SHIMOSAKA, M.; HAYASHIDA, N.; OKAZAKI, M. Effects of methyl jasmonate and elicitor on the activation of phenylalanine ammonia-lyase and the accumulation of scopoletin and scopolin in tobacco cell cultures. Plant Science, v.132, p.13-19, 1998.

SILVA, H.S.A.; ROMEIRO, R. da S.; MACAGNAN, D.; HALFELD-VIEIRA, B. de A.; PEREIRA, M.C.B.; MOUNTEER, A. Rhizobacterial induction of systemic resistance in tomato plants: non-specific protection and increase in enzyme activities. Biological Control, v.29, p.288-295, 2004.

STEINER, U.; SCHÖNBECK, F. Induced disease resistance in monocots. In: HAMMERSCHMIDT, R.; KUC, J. (Ed.). Induced resistance to disease in plants: developments in plant pathology. Dordrech: Kluwer Academic Pub., 1995. p.235-270.

STICHER, L.; MAUCH-MANI, B.; MÉTRAUX, J.P. Systemic acquired resistance. Annual Review of Phytopathology, v.35, p.235270, 1997.
VAN HUYSTEE, R.B. Some molecular aspects of plant peroxidase biosynthetic studies. Annual Review of Plant Physiology, v.38, p.205-219, 1987.

VAN LOON, L.C.; BAKKER, P.A.H.M.; PIETERSE, C.M.J. Induction and expression of PGPR-mediated induced resistance against pathogens. In: DUFFY, B.K.; ROSENBERGER, U.; DÉFAGO, G. (Ed.). Molecular approaches in biological control. Delémont: IOBC/WRPRS/EFPP, 1998b. p.103-110.

VAN LOON, L.C.; BAKKER, P.A.H.M.; PIETERSE, C.M.J. Systemic resistance induced by rhizosphere bacteria. Annual Review of Phytopathology, v.36, p.453-483, 1998a.

VAN LOON, L.C.; PIERPOINT, W.S.; BOLLER, T.; CONEJERO, V. Recommendations for naming plant pathogenesis-related proteins. Plant Molecular Biology Reporter, v.12, p.245-264, 1994.

WU, G.; SHORTT, B.J.; LAWRENCE, E.B.; LEVINE, E.B.; FITZSIMMONS, K.C.; SHAH, D.M. Disease resistance conferred by expression of a gene encoding $\mathrm{H}_{2} \mathrm{O}_{2}$-generating glucose oxidase in transgenic potato plants. Plant Cell, v.7, p.1357-1368, 1995.

Received on February 13, 2006 and accepted on May 2, 2006 